\title{
Acute compartment syndrome of the dorsal forearm following noncontact injury
}

\author{
Brent Crawford, MD; ${ }^{*}$ Sean Comstock, $\mathrm{MD}^{\dagger}$
}

\section{ABSTRACT}

Acute compartment syndrome is a limb-threatening condition in which early diagnosis and surgical consultation for fasciotomy are required to preserve functional outcome. The diagnosis is typically considered in patients with traumatic mechanisms of injury such as a direct blow and crush to the compartment, particularly when there is a fracture in the same compartment. We report the case of a patient with acute compartment syndrome of the dorsal forearm that occurred as a result of an atypical noncontact traumatic mechanism. Establishing the diagnosis of compartment syndrome was complicated in this patient, as some of the signs and symptoms of acute compartment syndrome could have been attributed to the presence of a coexisting rupture of the extensor digitorum muscle. This report serves to remind emergency physicians that, although rare, acute compartment syndrome can result from exertional and noncontact traumatic mechanisms.

Keywords: compartment syndrome, musculoskeletal diseases, forearm, trauma, injury, extensor digitorum muscle

\section{RÉSUMÉ}

Le syndrome des loges aigu est un état qui menace l'intégrité d'un membre pour lequel la précocité du diagnostic et la consultation chirurgicale pour fasciotomie sont essentielles à la préservation de la fonctionnalité. Le diagnostic est généralement envisagé chez les patients pour lesquels il s'agit d'un traumatisme de contact par choc direct et écrasement de la loge, en particulier en cas de fracture de la même loge. Nous présentons le cas d'un patient ayant un syndrome des loges aigu de la face dorsale de l'avant-bras consécutif à un mécanisme de traumatismes atypique sans contact. L'établissement du diagnostic de syndrome des loges aigu était compliqué chez ce patient, car certains des signes et symptômes du syndrome des loges aigu auraient pu être attribués à la présence d'une rupture coexistante du muscle extenseur commun des doigts. Ce rapport sert à rappeler aux médecins d'urgence qu'en dépit de sa rareté, le syndrome des loges aigu peut résulter d'efforts et de mécanismes de traumatismes sans contact.

\section{INTRODUCTION}

Acute compartment syndrome is a condition in which increased pressure within a closed tissue space compromises blood flow to muscles and nerves..$^{1-3}$ Early diagnosis, often done by emergency physicians, ${ }^{4}$ can avoid limb-threatening sequelae, which include permanent neurologic deficit, muscle necrosis, ischemic contracture, infection, delayed healing of underlying fractures and rhabdomyolysis. ${ }^{5}$ The diagnosis is typically considered in traumatic mechanisms such as a direct blow or crush injury to a compartment, particularly when these are accompanied by a fracture in the same limb. ${ }^{6,7}$ However, the diagnosis is easily missed when caused by exertional and noncontact mechanisms. ${ }^{8-11}$ The following case illustrates that acute compartment syndrome must also be included in the differential diagnosis of injuries to the forearm from noncontact mechanisms.

\section{CASE REPORT}

A previously well 26-year-old man was evaluated by the trauma team at a rural surgical centre 1 hour after a single-vehicle rollover motor vehicle crash that occurred at low velocity. The patient reported a sudden onset of pain in the dorsal left forearm that began while forcefully grasping the steering wheel in an attempt to prevent himself from being ejected from the cab of the truck as it rolled over. After life-threatening injuries had been excluded, a secondary survey revealed a visibly swollen forearm with exquisite pain to palpation over the dorsal aspect. This pain was aggravated by passive wrist flexion. The dorsal forearm felt tense compared with the uninjured side, and had a palpable defect at the

From the *Department of Emergency Medicine, Grey Nuns Community Hospital, Edmonton, Alta., and the †Department of Orthopaedic Surgery, Moncton Hospital, Moncton, NB

Submitted Dec. 1, 2009; Revised Jan. 8, 2010; Accepted Jan. 12, 2010

This article has been peer reviewed.

CJEM 2010;12(5):453-6 
junction of the middle and proximal third. The patient's wrist extension was weak compared with the contralateral side, particularly involving the second, third and fourth digits. Sensation, distal pulses, capillary refill and limb colour were normal and there were no defects in skin integrity. Hemoglobin and hematocrit levels and the international normalized ratio were within normal limits. Radiographs of the radius and ulna, elbow and wrist were normal.

The patient was felt to have a rupture of the extensor digitorum muscle, and the orthopedic service was consulted. At this time, approximately 2 hours after the motor vehicle crash, the patient continued to have pain out of proportion to what would be expected given the physical findings and negative radiographs, and pain on passive stretch of the muscles of the dorsal forearm compartment. He did not have paresthesia or paresis. Despite the temptation to attribute all the signs and symptoms to the muscle rupture, a dorsal compartment pressure was obtained by the orthopedic consultant using a Stryker intracompartmental monitoring system and was found to be $80 \mathrm{~mm} \mathrm{Hg}$. With the confirmed diagnosis of acute compartment syndrome, the patient was immediately taken to the operating room for a dorsal compartment fasciotomy approximately $10 \mathrm{~cm}$ in length (Fig. 1). A complete rupture of the extensor digitorum muscle was confirmed and a nonexpanding large hematoma found within the muscle defect (Fig. 2).

The patient's course in hospital was unremarkable. A washout, approximation of the muscle belly and closure of the skin was performed on postoperative day 2. The patient was advised to maintain the wrist splinted in extension for 2 weeks and was subsequently discharged from hospital with follow-up care.

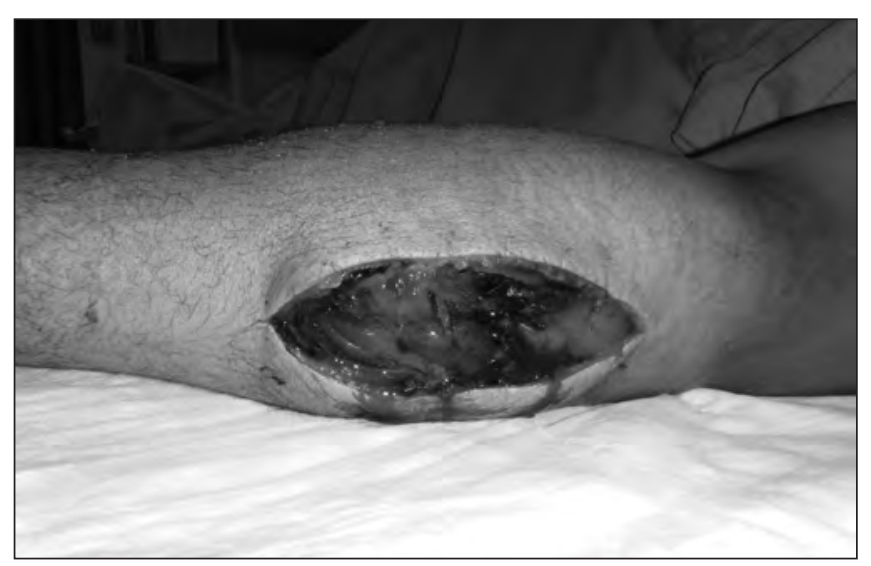

Fig. 1. Fasciotomy approximately $10 \mathrm{~cm}$ in length for de compression of compartment syndrome in the dorsal forearm of a 26-year-old man.

\section{DISCUSSION}

The key to successful treatment of acute compartment syndrome is early diagnosis in the emergency department. This begins with appropriate suspicion and with considering the possibility of the diagnosis based on the mechanism of injury. Compartment syndrome can occur after virtually any injury, but is most commonly associated with mechanisms of direct contact or crush injury. ${ }^{5}$ In one series detailing the causes of acute compartment syndrome in 164 cases, 69\% were associated with a fracture and $23 \%$ involved soft tissue injury without an associated fracture. ${ }^{12}$ The majority of cases without a fracture involved a direct blow to the affected muscle compartment or an injury with a major crushing mechanism. In $13 \%$ of cases without fracture, the etiology was deemed to be "spontaneous" secondary to exertional and noncontact mechanisms. This represented $3 \%$ of all cases of acute compartment syndrome seen. Interestingly, within the group of acute compartment syndrome due to soft tissue injury, $10 \%$ were either taking anticoagulants or had a bleeding disorder. ${ }^{12} \mathrm{~A}$ number of case reports exist describing acute compartment syndrome secondary to muscular rupture in the leg, and many conclude that noncontact mechanism as a cause of acute compartment syndromes is rare and easily missed..$^{8-11,13-16}$ Although we identified 3 case reports of exertional acute compartment syndrome of the dorsal forearm, ${ }^{17-19}$ to our knowledge, ours is the first such report associated with muscular rupture.

The clinical diagnosis of acute compartment syndrome is based on pain "out of proportion to stimulus," pain on passive stretch of the muscles of the involved

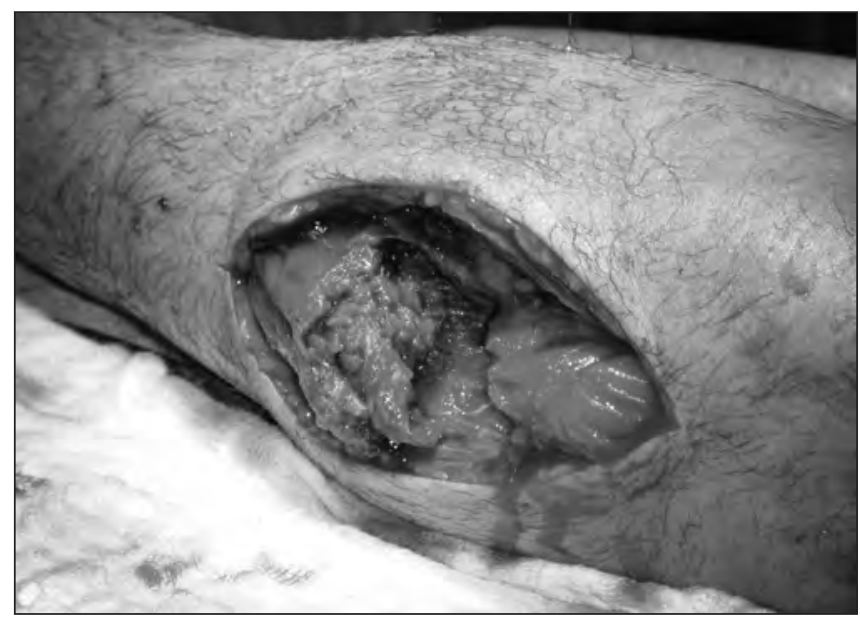

Fig. 2. Complete rupture of the extensor digitorum muscle and nonexpanding large hematoma within the muscle defect. 
compartment, paresthesia, decreased sensation to pinprick, light touch or 2-point discrimination, and eventually paresis. Individually, the sensitivity of these clinical findings ranges between $13 \%$ and $19 \%$, but the reported specificity and negative predictive values are $97 \%$ and $98 \%$, respectively, suggesting that clinical features are more useful to exclude rather than confirm the diagnosis. ${ }^{20}$ The pain of a coexisting injury, particularly a fracture, can mask that of an impending compartment syndrome ${ }^{7}$ undermining the diagnostic utility of pain and pain from passive stretch. ${ }^{5}$ Hypoaesthesia is the last clinical sign to develop before paresis, and only $13 \%$ of patients recover function when diagnosis is delayed until paralysis occurs. ${ }^{21}$ Diagnosis based on clinical signs and symptoms is difficult in patients who cannot provide a reliable history or participate in a physical examination. This includes patients with concomitant neurologic injury, critical illness or altered level of consciousness, and children. ${ }^{22}$

Measurement of intracompartmental pressure is the definitive test for compartment syndrome..$^{22,23}$ Urgent decompression is advised for measurements exceeding a threshold between $30 \mathrm{~mm} \mathrm{Hg}$ and $50 \mathrm{~mm} \mathrm{Hg}$, with $30 \mathrm{~mm} \mathrm{Hg}$ being the value most commonly cited. ${ }^{5,24}$ Other treatment triggers have also been suggested, such as a difference of $30 \mathrm{~mm} \mathrm{Hg}$ between either mean arterial pressure ${ }^{25}$ or diastolic blood pressure ${ }^{23}$ and the measured intracomparmental pressure.

The only effective therapy for acute compartment syndrome is surgical decompression of the affected compartments by fasciotomy. ${ }^{4}$ To preserve muscle function, fasciotomy should be performed within 6 hours of injury; ${ }^{5}$ however, even 3 hours from injury $37 \%$ of patients develop muscle necrosis. ${ }^{4}$ Catastrophic results are virtually inevitable if fasciotomy is delayed beyond 12 hours after the injury was sustained. ${ }^{7,27}$

\section{CONCLUSION}

Early diagnosis, based on appropriate suspicion from the mechanism of injury, signs and symptoms is the key to effective treatment of acute compartment syndrome. ${ }^{5}$ Soft tissue trauma that does not involve a direct blow, crushing forces or associated fracture is an uncommon but documented cause of acute compartment syndrome. ${ }^{12}$ The traditional diagnostic criteria of pain out of proportion to stimulus, pain on passive muscle stretch, paresthesia and paresis are individually insensitive and unreliable with certain patient groups. Such clinical criteria may be most useful when they are absent, to help exclude compartment syndrome. ${ }^{22}$ Measurement of intracompartmental pressure is the definitive test for compartment syndrome, and should be performed whenever the diagnosis is considered a possibility. ${ }^{22,23}$ A compartment pressure of $30 \mathrm{~mm} \mathrm{Hg}$ is most commonly cited as the threshold to initiate treatment. ${ }^{5,24}$ Fasciotomy should be performed as soon as possible after diagnosis, and ideally within 6 hours of injury, to preserve functional outcome. 5

Competing interests: None declared.

\section{REFERENCES}

1. Ashton H. Effect of inflatable plastic splints on blood flow. BMJ 1966;2:1427-30.

2. Shrier I, Magder S. Critical closing pressure and arterial resistance in an in vitro model of compartment syndrome. Med Sci Sports Exerc 1994;26(Suppl):S162.

3. Shrier I, Magder S. Pressure-flow relationships in in vitro model of compartment syndrome. I Appl Physiol 1995;79: 214-21.

4. Vaillancourt C, Shrier I, Vandal A, et al. Acute compartment syndrome: How long before muscle necrosis occurs? CJEM 2004;6:147-54.

5. Elliott KG, Johnstone AJ. Diagnosing acute compartment syndrome. J Bone Joint Surg Br 2003;85-B:625-32.

6. Geogiadis GM. Tibial shaft fractures complicated by compartment syndrome: treatment by immediate fasciotomy and locked unreamed nailing. 7 Trauma 1995;38:448-52.

7. McQueen MM, Christie J, Court-Brown CM. Acute compartment syndrome in tibial diaphyseal fractures. 7 Bone Joint Surg Br 1996;78:95-8.

8. Blandy JP, Fuller R. Ischemic myositis of the leg muscles from exercise. J Bone Joint Surg Br 1957;39:679-93.

9. Kirby NG. Exercise ischaemia in the fascial compartment of soleus. J Bone Joint Surg Br 1970;52:738-40.

10. McKee MD, Jupiter JB. Acute exercise-induced bilateral anterolateral leg comartment syndrome in a healthy young man. Am J Orthop 1995;24:862-4.

11. McHale KM, Prahinski JR. Acute exertional compartment syndrome occurring after performance of the army physical test. Orthop Rev 1994;23:749-53.

12. McQueen MM, Gaston P, Court-Brown CM. Acute compartment syndrome: Who is at risk? J Bone Joint Surg $\mathrm{Br}$ 2000;82-B:200-3.

13. Mohanna P-N, Haddad FS. Acute compartment syndrome following noncontact football injury. Br J Sports Med 1997; 31:254-5. 
14. Allen MJ, Barnes MR. Unusual cause of acute superficial posterior compartment syndrome. Injury 1992;23:202-3.

15. Moyer RA, Boden BP, Marchetto PA, et al. Acute compartment syndrome of the lower extremity secondary to noncontact injury. Foot Ankle 1993;14:534-7.

16. Williams P, Shenolikar A, Roberts RC, et al. Acute non-traumatic compartment syndrome related to soft tissue injury. Injury 1996;27:507-8.

17. Dhawan V, Borschel G, Brown D. Acute exertional compartment syndrome of the forearm. J Trauma 2008;64:1635-7.

18. Imbriglia JE, Boland DM. An exercise-induced compartment syndrome of the dorsal forearm: a case report. 7 Hand Surg [Am] 1984;9A:142-3.

19. Tompkins DG. Exercise myopathy of the extensor ulnaris muscle: report of a case. J Bone Joint Surg Am 1977;59:407-8.

20. Ulmer T. The clinical diagnosis of compartment syndrome of the lower leg: Are clinical findings predictive of the disorder? J Orthop Trauma 2002;16:572-7.

21. Bradley EL. The anterior tibial-compartment syndrome. Surg Gynecol Obstet 1973;136:289-97.
22. Shadgan B, Menon M, O'Brien P, et al. Diagnostic techniques in acute compartment syndrome of the leg. 7 Orthop Trauma 2008;22:581-7.

23. Tiwari A, Haq AI, Myint F, et al. Acute compartment syndromes. Br 7 Surg 2002;89:379-412.

24. Ho K, Abu-Laban RB. Ankle and foot. In: Marx JA, Hockberger RS, Walls RM, et al., editors. Rosen's emergency medicine: concepts and clinical practice. 5th ed. St. Louis (MO): Mosby; 2002. p. 706-37.

25. Mars M, Hadley GP. Raised compartment pressure in children: a basis for management. Injury 1998;29:183-5.

26. White TO, Howell GE, Will EM, et al. Elevated intramuscular compartment pressures do not influence outcome after tibial fracture. J Trauma Inj Infec Crit Care 2003;55:1133-8.

27. Mullett H, Al-Abed K, Prasad CV, et al. Outcome of compartment syndrome following intramedullary nailing of tibial diaphyseal fractures. Injury 2001;32:411-3.

Correspondence to: Dr. Brent Crawford, 18 Hamilton Cres., St. Albert AB T8N 6R6; bwecrawf@dal.ca

\section{Change of address}

We require 6 to 8 weeks' notice to ensure uninterrupted service. Please send your current mailing label, new address and the effective date of change to:

\section{Canadian Association of Emergency Physicians}

104-1785 Alta Vista Dr. Ottawa ON K1G 3 Y6

$613523-3343$

fax 613 523-0190

admin@caep.ca

\section{Changement d'adresse}

II nous faut de 6 à 8 semaines d'avis afin de vous assurer une livraison ininterrompue. Veuillez faire parvenir votre étiquette d'adresse actuelle, votre nouvelle adresse et la date de la prise d'effet du changement, à l'attention du

\section{Association canadienne des médecins d'urgence}

104-1785, prom. Alta Vista

Ottawa ON K1G 3 Y6

$613523-3343$

fax $613523-0190$

admin@caep.ca 